\title{
Real Estate Dynamics and Wealth Effect: A Theoretical Assessment
}

\author{
Wen Bao \\ College of Economics, Jinan University, Guangzhou, China \\ Email: rainiego@163.com
}

How to cite this paper: Bao, W. (2019) Real Estate Dynamics and Wealth Effect: A Theoretical Assessment. Modern Economy, 10, 1802-1811.

https://doi.org/10.4236/me.2019.107116

Received: June 10, 2019

Accepted: July 22, 2019

Published: July 25, 2019

Copyright $\odot 2019$ by author(s) and Scientific Research Publishing Inc. This work is licensed under the Creative Commons Attribution International License (CC BY 4.0).

http://creativecommons.org/licenses/by/4.0/

\section{(c) (i) Open Access}

\begin{abstract}
After the global financial crisis, more and more research at home and abroad have focused on the impact of the real estate market on consumer spending. This paper reviews the research results of domestic and foreign scholars on the wealth effect of real estate, and finds that no matter based on macro or micro data, the relevant domestic research has not given a more consistent conclusion that the wealth effect of the real estate market. Some people hold that the housing wealth effect is positive in China, while others hold that the housing wealth effect is negative in China. This paper sorts out those and tends to support the conclusion that the wealth effect of China's real estate market is negative. Then, based on the perspective of transmission mechanism, this paper makes a reasonable explanation, and finally puts forward some corresponding feasible policy recommendations to promote the positive wealth effect of the real estate market.
\end{abstract}

\section{Keywords}

Real Estate Price, Wealth Effect, Transmission Mechanism, Substitution Effect

\section{Introduction}

As an important part of the aggregate demand-consumption, the fluctuation of its expansion or contraction will have an important impact on macroeconomic operations. The wealth effect of the impact of assets on consumption has always been the focus of academic and economic decision-making institutions in the world. Early research on wealth effects at home and abroad focused on the impact of financial wealth on household consumption and less on housing assets. With the outbreak of the global financial crisis in 2008, the real estate market suffered heavy losses, which affected securities markets, banks and other finan- 
cial institutions, resulting in a sharp decline in consumer confidence and consumption capacity, causing economic recession. The outbreak of this crisis has made the domestic and international theoretical circles pay more attention to the wealth effect of the real estate market. The relationship between housing asset price volatility and household consumption behavior has become the focus of economics. The empirical study on the heterogeneity of the impact of housing price fluctuations on consumer spending has also become a hot spot and has received high attention from governments and relevant industry sectors.

The research on wealth effect abroad started earlier, and the research was deeper. And most empirical studies in developed economies have basically confirmed that the rise of real estate wealth not only has a positive and significant effect on household consumption, but also has a much larger wealth effect than the stock market. Different from this, the empirical research conclusions of Chinese scholars on this issue are different. Some scholars have come to the conclusion that China's rising house prices promote residents' consumption (Huang Jing and Tu Meizheng, Zhao Xiliang, Du Li, et al.). While some scholars have come to the conclusion that China's rising house prices restrain residents' consumption (Kuang Weida, Xie Jieyu, Chen Binkai and Yang Rudai, et al.) [1].

The article is organized as follows: The second part summarizes the related literature of housing wealth effect according to the data type. The third part is the analysis of the transmission mechanism of housing wealth effect. The fourth part is aimed at the real estate wealth effect on China, analyzing the limiting factors that restrict the real estate wealth effect and related countermeasures. The fifth part is the conclusion and research prospects.

\section{Literature Review}

\subsection{Theoretical Research on the Wealth Effect of Real Estate}

The basic principles of the wealth effect can be traced back to Pigou and Patinkin. The emphasis on the effect of changes in wealth stocks on total expenditures and total income is often referred to as the Pigou effect and the effect of real money balances. Pigou analyzed the nexus between real money balancesmoney supply divided by price level-and current consumption. He postulates that in periods of deflation (inflation), real money balances increase (decrease) and stimulate consumption, output and employment through the positive (negative) wealth effect they create. Thus, focusing on the real estate market, deflation will lead to an increase in the real value of properties and generate a positive wealth effect that would be channeled into more consumption. Such a wealth effect has been found by Kishor [2] in the case of this country. Then the advent of the theory of consumption function puts wealth into the factors that determine consumption, and provides a good theoretical support for quantitative analysis of wealth effects.

From the perspective of consumption function theory, the life cycle hypothesis of Ando and Modigliani [3] considers that consumers are rational, use their 
lifetime income according to the principle of utility maximization and arrange their lifetime consumption. Consumer spending in each period is The function of income and wealth, thus analyzing real estate wealth as a non-human wealth directly into the consumption function, provides a channel for property wealth to affect consumption, because the property held by individuals is part of their wealth; Friedman's theory of persistent income hypothesis holds that consumer spending is determined by its predictable long-term income, i.e., persistent income, providing a theoretical basis for explaining the conversion relationship between housing wealth and consumption; These two consumption theories that value the stock of wealth and future income, the former pay more attention to current wealth savings, while the latter pay more attention to future income expectations, but whether it is current actual savings or future income expectations, it is expressed as a kind of real wealth or virtualized wealth entering an important variable that affects consumption. Hall and Flavin integrated the life cycle theory and the persistent income hypothesis to form the LC-PIH model, which regards wealth as a key determinant of total consumption and more comprehensively explains the impact of real estate wealth effects.

The so-called wealth effect of real estate refers to the increase (or decrease) of the asset owner's wealth due to the rise (or decline) of the property price, thus affecting consumer demand and even social and economic growth. In theory, the overall effect of real estate wealth on consumer spending is uncertain, so it needs to be studied in more depth from an empirical perspective.

\subsection{Empirical Study on the Wealth Effect of Real Estate}

Domestic and foreign scholars mainly conduct empirical analysis on the wealth effect of the real estate market based on both macro and micro data. The research content mainly involves the existence test and size measurement of real estate wealth effect, the comparison of real estate wealth effect and stock market wealth effect, the degree of influence between different economies, and the heterogeneity study of real estate wealth effect.

Although some scholars abroad have questioned the existence of the wealth effect of real estate, such as Elliot [4] thought non-financial assets cannot be used as purchasing power, so they will not affect consumption. Levin [5] argues that the housing wealth effect does not exist and that consumption is not affected by housing prices. However, the empirical test of the real estate wealth effect in developed economies is more consistently considered that the impact of rising property wealth on household consumption is positive.

From the perspective of macro-capacity, Benjamin et al. [6] used macro data to test the relationship between house price and consumption, found that the two are positively correlated, and the property wealth effect is far greater than the stock market wealth effect. Case et al. [7] used the logarithmic form of US state data and panel data of OECD countries from 1982 to 1999, and concluded that real estate price increases have a significant positive effect on household consumption. Chen (2006) [8] analyzed the Swedish real estate quarterly data 
from 1980 to 2004 and concluded that upward fluctuations in housing prices have a positive and significant impact on household consumption. Research by Iacoviello [9] and Corroll et al. [10] affirmed the important impact of housing prices on consumption. Calomiris et al. [11] used the annual data of the US states from 1981 to 2009 to conclude that the housing asset wealth effect was significant.

The research conducted at the micro level can fully consider the characteristics of each family and analyze the heterogeneity of the impact of housing wealth on consumption. Skinner [12] used the US PSID data study to find that property income will stimulate young residents to expand consumption, but has no significant impact on the consumption behavior of elderly residents. Lehnert also believes that the wealth effect is more pronounced among young people. In contrast, Campbell and Cocco [13] used the relevant micro-data from the UK to argue that the impact of property appreciation on the consumption of older homeowners is more pronounced, while the effect of wealth on young renters is weaker. Calomiris et al. [14] based on their research in 2009, further considered factors such as age structure, wealth distribution and wealth structure, and concluded that the wealth effect is more significant when the proportion of young and old people is larger, the proportion of low-income population is larger and the proportion of housing assets in wealth is larger.

Domestic scholars have a relatively late start on the relationship between property wealth and consumption, and their research conclusions are controversial from both macro and micro perspectives. Most of the data used in domestic research from a macro perspective are national total time series or inter-provincial (city) panel data, subject to differences in data limitations and model selection, but the results are quite different. Such as Gao Chunliang, Luo Yuyan and Liu Dan based on macro data, found the real estate wealth effect is not obvious; The research of Zhang Hong, Song Bo, Wang Zilong et al. showed that the real estate market in China has a positive wealth effect. Song Bo [15] based on China's 1998-2006 real estate price and quarterly data on household consumption, Wang Zilong et al. [16] based on China's 1996-2007 real estate prices and quarterly data on household consumption using ECM research, China's housing price increase is The Granger cause of increased household consumption and has a positive wealth effect in China's real estate market. However, Hong Tao [17], Du Li et al. [18], Chen Jian et al. [19] believed that high housing prices have a depressing effect on household consumption.

In the study of the relationship between housing prices and consumption using domestic household microdata, some scholars believe that housing price increases actually promote household consumption, such as Huang Jing and $\mathrm{Tu}$ Meizeng, Zhao Xiliang et al., Zhao Weiya et al., Du Li, et al. [1]; Some scholars have also found that housing price increases have inhibited household consumption, such as Xiejieyu et al. [20] and Chen Binkai et al. [21]. Interestingly, Du Li et al. [18] based on 172 prefecture-level city data to empirically test the impact of real estate prices on residents' average propensity to consume, found that hous- 
ing price increases inhibited household consumption, and the property price impact path was divided into "wealth "Effects", "Post-employment spending pressure effect" and "property mortgage credit effect" to explain this negative real estate wealth effect; while $\mathrm{Du} \mathrm{Li}$ et al. [22] investigated the wealth effect of real estate in Shanghai, they found that the rise of housing prices in Shanghai generally increased the average consumption tendency of residents, and chose three mechanisms to explain the positive effect of rising housing prices on residents' propensity to consume: "wealth effect", "substitution effect" and "liquidity constraint effect".

It can be seen that the academic circles in China have not reached a consensus on the issue that the wealth effect of real estate in China is positive or negative.

\section{The Transmission Mechanism of Real Estate Wealth Effect}

In order to understand the effect of housing wealth on consumer spending in a more in-depth way, we need to analyze it by means of the transmission mechanism of wealth effect. Ludwig and Slok [23] discussed it earlier and argued that the channels of influence of housing price increase on household consumption can be divided into "realized wealth effect", "unrealized wealth effect", "budget constraint effect", "liquidity constraint effect" and "substitution effect".

\subsection{Realized Wealth Effect}

For property owners, rising house prices have increased their net wealth, which in turn has increased their current consumption. In addition, if the owner can obtain the proceeds through the relevant refinancing method or the sale of the property after the house price rises, the benefit will promote personal consumption.

\subsection{Unrealized Wealth Effect}

If house prices rise, even if the owner does not make a mortgage or sell the property to realize the proceeds, this unfulfilled wealth can still promote consumption. The reason is that the value of wealth discounts increases, and consumers will generate expectations that they are richer than ever.

\subsection{Budget Constraint Effect}

For renters who have no housing for a while, house prices have risen and rents have risen. With a certain budget constraint, renters have to reduce other consumption to pay higher rents. At the same time, rising house prices may also increase the cost of housing facilities and service prices, such as utilities and renovation costs. Thus, the effect of budgetary constraints may also have an effect on homeowners, squeezing their other aspects of their consumption.

\subsection{Liquidity Constraint Effect}

If the price of the property rises, the homeowner can apply for a higher amount 
of credit in the property with appreciation and gain greater liquidity. But this effect depends to a large extent on whether the real estate financial system is working well. On the other hand, if the real estate price drops sharply, the bank will reassess the value of the housing due to risk considerations, and at the same time require the housing to provide more new credit guarantees, thus increasing the liquidity constraints of consumers. Iacoviello et al. [9] and Campell et al. [13] further confirmed that credit conditions have an important impact on the wealth effect.

\subsection{Substitution Effect}

For potential buyers, they may choose to reduce other consumption to increase their savings in the face of higher housing prices. Research by Sheiner, Chen Jian, Yan Se and Zhu Guozhong confirmed the existence of such crowding [1]; For existing homeowners, the fiery development of the real estate market may lure them into the speculative ranks, and the proportion of investment spending has risen sharply to squeeze consumption.

Obviously, the realized and unrealized wealth effect and liquidity restraint effect mainly act on the owner of the house, emphasizing the promotion effect of rising house prices on individual consumption; while the budget restraint effect and substitution effect mainly act on the owner of the house, emphasizing the restraint effect of rising house prices on individual consumption. In theory, the overall effect of real estate wealth depends on the strength comparison of these effects, that is, the impact of housing prices on household consumption may be positive or negative. In short, the impact direction of housing prices on household consumption is uncertain. In addition, the transmission mechanism of the aforementioned real estate wealth effect is also influenced by the size and development of the real estate market, the liquidity of real estate, the maturity of the real estate financial market and people's attitude towards real estate wealth. There are differences in the exertion of the real estate wealth effect in different economies.

\section{Analysis of Wealth Effect in China's Real Estate Market}

\subsection{Constraints of Positive Wealth Effect of Real Estate in China}

Judging from the existing empirical research in China, this paper tends to accept the conclusion that the rise of real estate prices restrains the consumption of residents, that is, "wealth effect is negative" in China's housing market. Next, from the perspective of transmission mechanism of real estate wealth effect, this paper analyses the relevant factors that may restrict the positive effect of domestic real estate market.

From the perspective of realized and unrealized wealth effect, although China has carried out housing reform since the 1990s, the rate of housing ownership in China has reached $80 \%$ to $90 \%$. However, the calculation caliber of ownership rate in China is different from that in other countries. It does not mean the pro- 
portion of households with houses in the total number of households, but rather the proportion of private housing area in the total residential area. Therefore, the real proportion of households with houses is overestimated. And there are many homes for self-owned families from "house reform houses", and their housing conditions and satisfaction levels are generally not in place in one step, so this group of people is likely to belong to potential buyers. In addition, with the development of urbanization, the number of migrants who have entered the city is increasing and they live in cities all the year round. Even if they have houses in rural areas, they still want to buy houses locally. Therefore, the direct wealth effect on housing families is more restricted.

From the perspective of liquidity constraints, the key to increase consumption of households with real estate wealth is that households can obtain credit lines smoothly and conveniently through the real estate financial market. For example, in the United States, Sweden, the Netherlands and other Western countries, consumers can use financial products such as reverse mortgage loans and mortgage credit to obtain the income of real estate value-added and enhance their consumption capacity. In this respect, the development of China's real estate financial market is relatively lagging behind, the related financial products are limited, and the secondary market of housing mortgage loan is not developed enough, the information channel is not smooth, the corresponding supporting design of loan insurance is missing, the families with multiple properties lack convenient channels to realize value-added wealth, thus restricting the development of the "credit effect". Secondly, many developed countries, such as the United States, have implemented the HMID system, that is, the parties can deduct the interest of the mortgage loan with their houses as security before paying the personal income tax. This gives the real estate families certain pre-tax credits, reduces the interest cost of the family's refinancing when the houses are mortgaged, and further stimulates the family's consumption tendency, thus expanding Housing Mortgage Credit Effect. However, there is no such preferential system of deduction before tax in our country.

From the perspective of liquidity restraint effect and substitution effect, on the one hand, for the existing tenants, the rising housing market causes the rent price to rise, which will increase the rental cost of the tenants, and will occupy other expenditures under the income restraint; On the other hand, for potential buyers, the down payment ratio of commercial housing loans in China is set at $30 \%$, the requirement is so high that most of them cannot meet the down payment standard. Facing rising housing prices, they can only choose to increase the current savings or increase the number of savings periods. Secondly, the rental market which has a certain degree of substitution relationship with the purchase of houses is not perfect. China's affordable housing construction, especially low-rent housing construction, is seriously absent; coupled with the private rental housing market is not standardized enough, so a large number of homeless people have to delay or abandon some expected consumption and investment to 
increase current savings to cope with rising housing prices. Mortgage buyers have to reduce their consumption in other areas to repay their loans; families with "house-to-house" and other families who are dissatisfied with existing housing have strong replacement needs, and they have to save deposits and postpone consumption in order to purchase more comfortable housing; existing real estate owners are attracted by the high income of the housing market, joining the ranks of "real estate speculation", speculative spending crowd out other consumer spending.

\subsection{Measures to Promote Positive Wealth Effect in China's Real Estate Market}

On the one hand, China should further attach importance to and promote the development of real estate financial market, improve the construction of housing mortgage loans and other supporting systems, timely promote the construction of real estate reverse mortgage loans and housing mortgage secondary market, and actively respond to the reform of personal income tax system. Drawing lessons from the experience of developed cities, Carry out the pre-tax deduction system for residential mortgage loans, which will help real estate families achieve positive mortgage credit effects when housing prices rise; Innovate corresponding financial products and services, and appropriately lower the down payment standards for housing purchases. Let more residents who are temporarily facing liquidity constraints have their own houses to alleviate the crowding out effect of homeless people; At this stage, in view of the lack of investment channels for residents, China should actively cultivate multi-faceted, multi-level and diversified investment markets. In order to adapt to the increasing financial investment needs of the nationals, it is also conducive to changing the social atmosphere in which the people will go to the housing market and push up the housing prices when they have money.

On the other hand, China should further develop and improve the housing security system. Apart from the development of low-rent housing and public rental housing with good quality at the government level, it can also promote the rental demand by drawing on the relevant experience of foreign institutions to cultivate renters through market-oriented methods. Furthermore, through the standardization and integration of the existing private house rental market, we can cultivate a more mature real estate rental market, so that the homeless can enjoy a comfortable life through renting. Purchasing houses and renting houses are alternative ways of living. Establishing a standard and comfortable rental market is conducive to attracting more homeless people into the ranks of renting houses, playing a role of diversion, weakening the rigid demand for house purchasing, alleviating the crowding-out effect of potential buyers, and helping to release the consumer demand that was restrained by purchasing houses. This has a long-term and important practical significance for expanding consumption, sharing the fruits of social development and promoting the growth of social wealth. 


\section{Conclusions}

Ideally, the stock market or the housing market can act as a "barometer" for the national economy. The real estate market and the economic operation should be positively related: when the economic trend is good, the housing prices will rise, and the higher asset prices will drive the wealth effect and stimulate the national consumption, thus driving macroeconomic development, both of which should present a virtuous circle.

However, there are some constraints in the reality that hinder the positive wealth effect of the Chinese real estate market. This paper analyzes these factors in combination with the transmission mechanism of wealth effect, and puts forward relevant policy recommendations, trying to make a certain reference for how to carry out correct house price regulation and related system construction to boost China's residents' consumption and expand domestic demand.

In addition, based on the above-mentioned literature, this paper extracts the direction of further research on the wealth effect of housing in China: introducing Chinese characteristics and strengthening theoretical modeling analysis. Although the wealth effect needs to be verified by empirical analysis to a large extent, the necessary theoretical modeling analysis is indispensable. This requires the full consideration of "land finance", huge currency issuance, traditional concepts, credit constraints and other Chinese characteristics in the model. This helps to understand why there are such obvious differences in housing wealth effects between China and the Western developed countries, such as Britain and the United States.

\section{Conflicts of Interest}

The author declares no conflicts of interest regarding the publication of this paper.

\section{References}

[1] Zhou, H.D. (2013) The Mystery of China's Housing "Wealth Effect": A Literature Review. Consumer Economics, 31, 79-85.

[2] Kishor, N.K. (2007) Does Consumption Respond More to Housing Wealth than to Financial Market Wealth? If So, Why? The Journal of Real Estate Finance and Economics, 35, 427-448. https://doi.org/10.1007/s11146-007-9080-4

[3] Ando, A. and Modigliani, F. (1963) The "Life Cycle" Hypothesis of Saving: Aggregate Implications and Tests. The American Economic Review, 53, 55-84.

[4] Elliott, J.W. (1980) Wealth and Wealth Proxies in a Permanent Income Model. The Quarterly Journal of Economics, 95, 509-535. https://doi.org/10.2307/1885091

[5] Levin, L. (1998) Are Assets Fungible? Testing the Behavioral Theory of Life-Cycle Savings. Journal of Economic Behavior and Organization, 36, 59-83. https://doi.org/10.1016/S0167-2681(98)00070-5

[6] Benjamin, J.D., Chinloy, P. and Jud, G.D. (2004) Real Estate versus Financial Wealth in Consumption. The Journal of Real Estate Finance and Economics, 29, 341-354. https://doi.org/10.1023/B:REAL.0000036677.42950.98 
[7] Case, K.E., Quigley, J.M. and Shiller, R. (2005) Comparing Wealth Effects: The Stock Market versus the Housing Market. Advances in Macroeconomics, 5, 1-32. https://doi.org/10.2202/1534-6013.1235

[8] Chen, J. (2006) Re-Evaluating the Association between Housing Wealth and Aggregate Consumption: New Evidence from Sweden. Journal of Housing Economics, 15, 321-348. https://doi.org/10.1016/j.jhe.2006.10.004

[9] Lacoviello, M. and Minettl, R. (2008) The Credit Channel of Monetary Policy: Evidence from the Housing Market. Journal of Macroeconomics, 30, 69-96. https://doi.org/10.1016/j.jmacro.2006.12.001

[10] Carroll, C.D., Otsuka, M. and Slacalek, J. (2011) How Large Are Housing and Financial Wealth Effects? A New Approach. Journal of Money, Credit and Banking, 43, 55-79. https://doi.org/10.1111/j.1538-4616.2010.00365.x

[11] Calomiris, C., Longhofer, S.D. and Miles, W. (2009) The (Mythical?) Housing Wealth Effect. National Bureau of Economic Research, Cambridge, No. w15075. https://doi.org/10.3386/w15075

[12] Skinner, J. (1996) Is Housing Wealth and Aggregate Saving. Regional Science and Urban Economics, 19, 305-324. https://doi.org/10.1016/0166-0462(89)90008-2

[13] Campell, J.Y. and Cocco, J.F. (2007) How Do Housing Prices Affect Consumption? Evidence from Micro Data. Journal of Monetary Economics, 54, 591-621. https://doi.org/10.1016/j.jmoneco.2005.10.016

[14] Calomiris, C.W., Longhofer, S.D. and Miles, W. (2012) The Housing Wealth Effect: The Crucial Roles of Demographics, Wealth Distribution and Wealth Shares (No. w17740). National Bureau of Economic Research, Cambridge. https://doi.org/10.3386/w17740

[15] Song, B. (2007) Theoretical Analysis of Wealth Effect in Real Estate Market and Empirical Test of Chinese Experience: 1998-2006. Economic Science, 5, 41-53.

[16] Wang, Z.L. and Xu, X.D. (2011) Research on Generalized Virtual Wealth Effect Measurement in Real Estate Market. China Industrial Economics, 3, 15-25.

[17] Hong, T. (2006) Real Estate Price Fluctuation and Consumption Growth: Empirical Analysis and Theoretical Explanation Based on Chinese Data. Nanjing Social Science, 5, 54-58.

[18] Du, L., Pan, C.Y., Zhang, S.Y. and Cai, J.N. (2010) The Rise in Housing Prices Promotes or Inhibits Household Consumption-An Empirical Study Based on Panel Data of 172 Prefecture-Level Cities in China. Zhejiang Social Sciences, No. 8, 24-30.

[19] Chen, J., Chen, J. and Gao, B. (2012) Research on Credit Constraints, Housing Prices and Resident Consumption Rate u Based on Panel Threshold Model. Journal of Financial Research, No. 4, 45-57.

[20] Xie, J.Y., Wu, B.Z. and Li, H.B. (2012) Housing Price and Household Consumption in China. Journal of Financial Research, No. 6, 13-27.

[21] Chen, B.K. and Yang, R.D. (2013) Land Supply, Housing Price and China Urban Residents' Savings. Economic Research Journal, 1, 110-122.

[22] Du, L., Shen, J.G. and Pan, C.Y. (2013) Empirical Research on the Impact of Rising House Prices on the Average Consumption Tendency of Urban Residents uu Based on the Data of Shanghai Household Survey. Journal of Financial Research, No. 3, 44-57.

[23] Ludwig, A. and Sløk, T. (2002) The Impact of Changes in Stock Prices and House Prices on Consumption in OECD Countries. No. 1, International Monetary Fund, Washington DC. https://doi.org/10.5089/9781451841640.001 